\title{
DEMOCRACY AND GOVERNANCE NETWORKS: COMPATIBLE OR NOT?
}

\section{Four Conjectures and their Implications for Theory and Practice ${ }^{1}$}

\author{
Erik-Hans Klijn, \\ Department of Public \\ Administration, \\ Erasmus University, \\ The Netherlands
}

And Chris Skelcher,
School of Public Policy,
The University of
Birmingham,
UK

Published in: Public Administration (2008) vol 85 no.3: 587-608

\section{Address for correspondence:}

\author{
Dr. E.H. Klijn \\ Department of Public Administration \\ Faculty of Social Science \\ Erasmus University Rotterdam \\ P.O. Box 1738 \\ 3000 DR Rotterdam \\ The Netherlands \\ klijn@fsw.eur.nl
}

december 2005

\footnotetext{
${ }^{1}$ Two ESRC awards have supported the research for this paper. Klijn was supported by an ESRC/EPSRC Advanced Institute of Management Research (AIM) International Visiting Fellowship, under Award RES-33130-000129. Skelcher was supported by ESRC Research Award RES-000-23-1295 'Democratic anchorage of governance networks in three European countries'
} 


\title{
DEMOCRACY AND GOVERNANCE
}

\author{
NETWORKS: COMPATIBLE OR NOT?
}

\section{Four Conjectures and their Implications for Theory}

\author{
and Practice
}

\begin{abstract}
The relationship between representative democracy and governance networks is investigated at a theoretical level. Four conjectures about the relationship are defined. The incompatibility conjectures rests on the primacy of politics and sees governance networks as a threat. The complementarity conjecture presents governance networks as a means of enabling greater participation in the policy process and sensitivity in programme implementation. The transitional conjecture posits a wider evolution of governance forms towards network relationships. The instrumental conjecture views governance networks as a powerful means through which dominant interests can achieve their goals. Illustrative implications for theory and practice are identified, in relation to power in the policy process, the public interest, and the role of public managers. The heuristic potential of the conjectures is demonstrated through the identification of an outline research agenda.
\end{abstract}




\section{PROBLEMATICS OF DEMOCRACY AND NETWORKS}

Academics, policy makers and public managers across Europe are devoting considerable attention to the problem of understanding, influencing and working through governance networks. We use the term 'governance network' to describe public policy making and implementation through a web of relationships between government, business and civil society actors. Governance networks are associated with new systems for public policy deliberation, decision and implementation (Pierre and Peters 2000; Koppenjan and Klijn 2004). They are based on interdependencies, but not necessarily equity, between public, private and civil society actors. ${ }^{2}$ They move beyond the institutionalised peak bargaining of corporatism to more dispersed, flexible and, in some cases, transparent modes of agenda setting, policy making and implementation. Governance networks are often associated with new hybrid organisational forms that play a major role in shaping and delivering public policy to citizens and communities, including quasi-governmental agencies, public-private partnerships, and multi-organisational boards. These institutions have the potential to generate efficiency gains when formulating and implementing public policy by integrating organisations across policy boundaries and having greater legal flexibility, but can have weaknesses in their democratic standing where there is loose coupling to formal governmental institutions (Sullivan and Skelcher 2002).

\section{The central problem}

The relationship between representative democracy and governance networks deserves closer scrutiny. There is only limited scientific evidence available to date. In the absence of

\footnotetext{
${ }^{2}$ The order of the words 'governance' and 'network' is important. Our usage - governance network emphasises that the network relationships we are considering are specifically those concerned with governance, that is the articulation, resolution and realisation of public values in society. The alternative (and more usual) word order - network governance - we see as being a higher level concept associated with a particular mode of societal organisation, which is usually contrasted with market and hierarchy.
} 
evidence, the debate has been polarised. One view sees networks as arenas that offer new ways of connecting public policymaking to citizens and stakeholders, overcoming the constraints and limitations of representative democracy and party politics. This literature emphasises the pluralist notion of networks as consisting of horizontal interdependencies through which actors steer the development of policy and its implementation. Such networks are understood to be flexible and fluid, able to adapt to accommodate the new forms of interest representation associated with deliberative practices (Hajer and Wagenaar 2003). The contra view is that networks are centres of power and privilege that give structural advantage to particular private interests in the process of making or shaping public policy decisions (Lowndes 2001). This critique of the pluralist position emphasises the strong managerial character of governance networks, their incorporation of strategically powerful actors, and the opacity of their formal rules and constitutional position (MacKinnon 2000; Davies 2002).

Recently, there has been a growth in research that sets out to investigate more systematically the democratic dimension of governance networks, and the partnership boards through which many find formal expression. This literature includes Sørensen and Torfing’s (2003) analysis of Danish civic networks, Walti, Kübler and Papadopoulos (2003) who investigated drug control boards in Switzerland, Edelenbos and Klijn’s (2006) work on politicians' responses to interactive decision-making with citizens, and Skelcher, Mathur and Smith’s (2005) inquiry into the discursive construction of institutional rules and practices in English partnerships. ${ }^{\mathrm{i}}$

\section{Focus of this article}

This developing stream of research on the democratic dimension of governance networks has thus far has failed to trace through the range of theoretical linkages between governance networks and representative democracy. The duality identified above - networks support or 
restrict democracy - are only two in a quartet of potential causal relationships. The other two conjectures suggest that governance networks either mark a transitional stage in the democratic process of public policy making, or are an instrument of domination by powerful forces. This article explores these four perspectives. We ask whether and how governance networks connect to the processes of representative democracy to which European nation states and their sub-national governments aspire, and which forms the basic mode of interest intermediation and public accountability for governmental action. In doing so, our purpose is to provide a stronger theoretical and analytical foundation to the emerging research effort on democracy and governance networks, and to indicate the key questions it might address in the next few years. The article concludes by drawing out some of the implications of our analysis for the theory and practice of public administration.

\section{FOUR CONJECTURES ON DEMOCRACY AND NETWORKS}

\section{A framework for analysis}

We present the relationship between representative democracy and governance network as 'conjectures'. Conjectures are tentative theories designed to offer provisional solutions to problems. The value of a conjecture is to generate fresh thinking, investigation and insight. They are more akin to informed speculations that provide a framework from which more detailed empirical and theoretical research questions can be established, and investigations undertaken. The conjectures are heuristic tools to structure the discussion about the relation between governance networks and representational democracy. They organise the literature on this topic and can be used to highlight particular themes or tensions that impact on theory or practice. In this way, the conjectures can be used to develop propositions for empirical 
research. In this article we are first concerned with constructing the conjectures and connect them to the existing literature, and then to identify themes.

We see four important conjectures in the relationship between representational democracy and governance networks: the incompatible, complementary, transitional, or instrumental conjectures. The first two conjectures are polar opposites, rooted in different theoretical traditions. The third and fourth conjectures are of somewhat different nature. They are concerned with, respectively, the adaptation necessary when a governance system changes, and the use of that new system by authoritative actors. Although our reading of the literature inspires the content of the conjectures, they are in the first place a construction with an internal logic. They tell a consistent story. This structures the various arguments that can be found in the literature. However individual authors will and do use lines of arguments that locate in different conjectures. In that sense each conjectures is an abstract construction and does not necessarily reflect the views of the authors we cite.

If the conjectures are heuristic tools, then comparison between their overall logic and internal elements becomes important. We describe each conjecture in terms of five characteristics that we think convey the core information necessary for comparison: their view of democracy, the role of elected politicians, their view of decision-making, and of accountability. The views of democracy and of the role of elected politicians are obvious since we want to explore the relation between representational democracy and governance networks. But the view of decision-making is just as important because that tells something about how the four conjectures look at public policy-making and the place of elected politicians in this. We include views of accountability because they provide an avenue into important contemporary issues about how accountability relationships of governance networks are arranged (table 1). 
TABLE 1 Four conjectures on the relationship of governance networks to democratic institutions

\begin{tabular}{|c|c|c|c|c|}
\hline Conjecture & 1: Incompatible & 2: Complementary & 3: Transitional & 4: Instrumental \\
\hline \multicolumn{5}{|l|}{ Characteristics } \\
\hline $\begin{array}{l}\text { Relationship of } \\
\text { governance } \\
\text { networks to } \\
\text { representative } \\
\text { democracy }\end{array}$ & $\begin{array}{l}\text { Governance networks challenge } \\
\text { legitimacy and decision rules of } \\
\text { representative democratic institutions }\end{array}$ & $\begin{array}{l}\text { Governance networks provide } \\
\text { democratic institutions with additional } \\
\text { linkages to society }\end{array}$ & $\begin{array}{l}\text { Governance networks offer greater } \\
\text { flexibility and efficiency than } \\
\text { representative democratic institutions, } \\
\text { they will increase as the primary mode } \\
\text { of societal decision-making, at the } \\
\text { expense of representative democratic } \\
\text { institutions }\end{array}$ & $\begin{array}{l}\text { Governance networks provide a means } \\
\text { for representative democratic institutions } \\
\text { to increase their authority in the face of } \\
\text { societal complexity }\end{array}$ \\
\hline $\begin{array}{l}\text { View of } \\
\text { democracy }\end{array}$ & $\begin{array}{l}\text { Representative democracy should be the } \\
\text { primary means of societal decision- } \\
\text { making }\end{array}$ & $\begin{array}{l}\text { Representative democracy has primacy } \\
\text { for decisions affecting fundamental } \\
\text { values, but for other types of decisions it } \\
\text { can co-exist with deliberative and } \\
\text { participative democracy introduced } \\
\text { through governance networks }\end{array}$ & $\begin{array}{l}\text { Representative democracy is being } \\
\text { replaced by other modes of societal } \\
\text { decision-making that reflect plural } \\
\text { weighting of values in a diverse world }\end{array}$ & $\begin{array}{l}\text { Representative democracy reasserts } \\
\text { itself, by working through procedures } \\
\text { that are less subject to public scrutiny } \\
\text { and accountability, and emphasising } \\
\text { agreement over outputs rather than } \\
\text { inputs to the decision process }\end{array}$ \\
\hline $\begin{array}{l}\text { Role of elected } \\
\text { politicians }\end{array}$ & $\begin{array}{l}\text { Politicians are decisive at crucial points } \\
\text { and their electoral authority should not } \\
\text { be undermined by introducing } \\
\text { alternative democratic modes }\end{array}$ & $\begin{array}{l}\text { Politicians try to cope with complexity } \\
\text { by using networks to increase } \\
\text { involvement in policy formulation, thus } \\
\text { strengthening input legitimacy. But at } \\
\text { the same time their electoral authority } \\
\text { gives them a special role in the goal } \\
\text { setting process and means that they } \\
\text { should be the final arbiters between } \\
\text { competing views }\end{array}$ & $\begin{array}{l}\text { Politicians within a representative } \\
\text { democratic system are unable to } \\
\text { accommodate the complexities of the } \\
\text { modern world; they should act as meta- } \\
\text { governors (mediators and referees) }\end{array}$ & $\begin{array}{l}\text { Politicians try to cope with complexity } \\
\text { by using governance networks as a } \\
\text { means to control actors and realise } \\
\text { policy, by emphasising output legitimacy } \\
\text { and should be more 'emphatic' to other } \\
\text { actors }\end{array}$ \\
\hline $\begin{array}{l}\text { View of } \\
\text { accountability }\end{array}$ & $\begin{array}{l}\text { Primary accountability lies with the } \\
\text { elected political officials (classical } \\
\text { accountability) }\end{array}$ & $\begin{array}{l}\text { Accountability is shared between } \\
\text { political office holders and other actors, } \\
\text { multiple forms of accountability are } \\
\text { added to the classical political } \\
\text { accountability (performance indicators, } \\
\text { boards, etc) (shared accountability) }\end{array}$ & $\begin{array}{l}\text { Accountability is in the first place } \\
\text { achieved by checks and balances in the } \\
\text { decision-making process, by securing the } \\
\text { openness of decision-making and } \\
\text { enhancing transparency of decision- } \\
\text { making by multiple forms of } \\
\text { accountability (constructed } \\
\text { accountability) }\end{array}$ & $\begin{array}{l}\text { Accountability is secured by the } \\
\text { dominant role of elected politicians. } \\
\text { Other forms of accountability (like } \\
\text { performance indicators) are used by } \\
\text { political official holders to control other } \\
\text { actors and the decision-making process } \\
\text { as a whole (instrumental accountability) }\end{array}$ \\
\hline $\begin{array}{l}\text { View of } \\
\text { decision- } \\
\text { making }\end{array}$ & $\begin{array}{l}\text { Decision-making takes place in closed } \\
\text { networks that lack sufficient steering by } \\
\text { or accountability to representative } \\
\text { democratic institutions }\end{array}$ & $\begin{array}{l}\text { The increasing complexity of decision- } \\
\text { making requires governance networks in } \\
\text { order to bring relevant actors into the } \\
\text { process; politicians should focus on the } \\
\text { main decisions, and devolve lower level } \\
\text { decisions to governance networks }\end{array}$ & $\begin{array}{l}\text { Modern society inherently is } \\
\text { characterised by networks and complex } \\
\text { decision-making with interdependencies; } \\
\text { the information revolution and } \\
\text { globalisation create new societal } \\
\text { complexities; institutions created in the } \\
\text { age of democracy are no longer adequate }\end{array}$ & $\begin{array}{l}\text { Decision-making is complex, but takes } \\
\text { place under the 'shadow of hierarchy'. }\end{array}$ \\
\hline
\end{tabular}


This overall framework enables us to establish what binds and what divides these conjectures. What binds these conjectures is the agreement of an empirical state of affairs: decisionmaking is complex and messy, many interest groups are trying to influence public policy making, and this decision process takes place in a multi-actor setting (Rhodes 1988; Laumann and Knoke 1987; Milward and Wamsley 1985; Hjern and Porter 1981; Bardach 1977). The differences between the four perspectives are mainly a matter of theorising and interpretation of the empirical phenomenon and of the normative criteria that are used to make judgements about it as can be seen from table 1. There are differences in the theoretical perspective on the characteristics of the process of public policy making, the central or peripheral place of elected office holders in this process, and the normative judgement of the empirical phenomena and the proposed solutions to improve decision-making processes. In particular, there are differences in relation to the principle of the primacy of politics. This principle accords ultimate decision-making authority to elected politicians within a system of democracy (Dogan 1975; Koppenjan and Klijn 2004). It is clearly fundamental to the incompatibility conjecture (conjecture 1), and to some extent the instrumental approach (conjecture 4). However it is challenged by the transitional conjecture (conjecture 3) and 'softened’ by the complementary conjecture (conjecture 2).

\section{Conjecture 1: the Incompatibility Conjecture}

The incompatibility thesis argues that representative democracy and governance networks conflict because each is predicated on a different set of institutional rules. This line of reasoning goes back to the literature on iron triangles and subsystems. Freeman and ParrishStevens (1987) trace a strong negative judgement about the iron triangles in earlier literature, explaining that the primacy of politics and the image of the general interest are threatened by the involvement of networks of actors, who create complex and partly horizontal interactions 
around the content and implementation of public policy. This challenge increases in line with the degree of closure of these networks of actors.

The incompatibility perspective focuses on the inherent tension between the rules for representational democracy and the empirical practice and implicit rules of governance networks. Sørensen (2002) gives a detailed account of why representative democracy and governance networks are potentially incompatible. She argues that there are four factors. First, governance networks lead to a multi-level system in which there is a degree of shared sovereignty between national, sub-national and supra-national institutions. This challenges the hegemony of the state and, by implication, the construction of 'the people' as the selfregulating sovereign. Second, the emergence of governance networks reconstitutes the notion of political representation. From being an expression of the political will of the people, through the electoral and other processes of representative democracy, it becomes a terrain contested between a multitude of actors. Third, she argues that public administrators become more active in the policy process because of their role in facilitating and coordinating governance networks. This places the role of the public administrator in the democratic process in a new light. Fourth, Sørensen suggests that traditional theories of representative democracy see a separation between the political system and society. Governance networks challenge this separation, and indeed is constructed precisely on the basis of its potential to engage multiple actors across the boundary between state, market and civil society.

Within this perspective there is much attention to the closed nature of decision-making and the sector character of decision-making. In that sense this perspective on decision-making builds strongly on earlier work by political scientists like Ripley and Franklin (1987), who state that sub-governments - clusters of individuals that effectively make most of the routine 
decisions in an area of policy - are widely present. This interest in sectorization of decisionmaking pays attention to its closed character, but also to the compartmentalization of decision-making in separate policy sectors (see also Rhodes 1988; Laumann and Knoke 1987; Koppenjan et al 1987). And it stresses the limited accessibility of the decision-making arenas for non-specialised non-organised interest groups. The relative closed nature of decisionmaking and the sector character results in a dominant involvement of sector specialists, tending to increase the participation of technical actors and specialists appointed to quasigovernmental bodies at the expense of elected politicians (Heisler 1974; Koppenjan et al 1987). This is evident in, for example, policy making on some areas of European policy, transportation, defence and health (Marsh and Rhodes 1992; Wamsley 1985). Consequently the literature is interested in the way governance networks interfere with the principles of the primacy of politics and the political accountability of ministers and other elected, executive officeholders. Since accountability in this conjecture is reserved for political office holders the conjecture tends to take a critical stance towards accountability being threatened by governance networks.

The incompatibility thesis has taken a significant hold on academic debate. It is a tradition with a long history and many proponents, especially in terms of the idea of the 'democratic deficit’ applied to European policy making and to quasi-government at national, regional and local levels. However it is not without its critics. Papadopoulos (2003) warns that it is subject to two main limitations. The first constraint is that it develops its critique on the basis of an idealised and somewhat classical view of representative democracy. This perspective, Papadopoulos argues, fails to take account of recent modifications to which it has been subject in the theoretical and empirical literature. For example, the role of elections and the process of policy making is more complex than this theory suggests. The second problem 
identified by Papadopoulos is that the discussion takes little account of the complexities of accountability in contemporary liberal democracies. To this we add the observation that governance networks may offer one route to enhanced accountability precisely because it has the potential to draw more actors into a process of deliberative policy making and implementation.

\section{Conjecture 2: the Complementarity Conjecture}

The second conjecture emphasises the complementary of governance networks to representative democracy. From this perspective, governance networks engage a wider range of actors in the policy process, connecting them in new ways, and thus oils the wheels of representative democracy as it struggles to govern in a complex environment (Rhodes 1988; Pierre and Peters 2000). This line of argument starts from the premise that the contemporary complexities of governance in advanced liberal democracies poses major problems for representative democratic institutions designed on the basis of simpler operating environments. The complexities arise in two ways. First, complexities emerge from the nature of the choices facing governments (Koppenjan and Klijn 2004). Examples include the agenda for global action across national boundaries to resolve problems of environmental decay and terrorism, the intractable problems of human rights arising from advances in biotechnology, and the tensions between individual freedom and collective responsibility involved in reducing anti-social behaviour in neighbourhoods. These stretch government by bringing public policy into new arenas and relationships. Second, complexities are created because these new agendas are superimposed on the earlier cleavages in society around which constitutional arrangement in advanced liberal states were designed, as Lijphart (1984) shows in his analysis of governmental systems. For example, the US constitution set out to manage the relationship between individual liberty and public purpose, while that in the Netherlands 
was constructed to enable collective decisions to be made across religious and cultural differences. New cleavages in society around religion, ethnicity, cultural orientation, sexuality, and so on pose challenges for representative democratic systems based on older constitutional settlements. Although constitutions have evolved, and been replaced in some cases, the conditions upon which representative democracy operates are tested by the complexity of contemporary public policy problems, the forms through which citizens can participate (e.g. global protests, single issue direct action) and the informatics that support this (e.g. the internet, instantaneous global news coverage, the g3 phone). The implications of this tension for citizens' attitudes to government is not firmly established, but is understood to be one of disenchantment and lowered propensity to engage with electoral processes and other constitutionally-defined means of political choice and legitimation.

From a practical perspective, governance networks offer a flexible means of institutional design to mediate the relationship of representative democracy with citizens and other parties, thus ameliorating the problems set out above. It achieves this through the creation of quasigovernmental institutions within which civil society and business actors can interact with public servants, thus engaging them more fully in the public policy process. The domain of these institutions is typically defined in terms of a specific functional realm, in the sense that they address a single policy problem or goal, for example revitalising a neighbourhood or improving recycling of waste. This perspective draws on the policy networks approach set out by Marsh and Rhodes (1992), a conceptualisation of the incorporation of pressure groups, experts and other key actors into structured relationships with government. However there are two important differences between scholars working in the policy networks tradition and the more recent concerned with governance networks. One difference is that the extent of participation in the latter is understood to be wider. Klijn and Koppenjan (2000: 368) 
comment, "the circle of participants is not limited to existing institutionalised forms of interest representation. Rather it is characterised by the opening up of existing arenas of decision making to new actors, new interest groups, other authorities, private organizations, citizens and users”. The other difference is that the central research problems are different. Policy network researchers are typical interested in the way that network structure affects policy outcomes, while those working within the governance network framework also point to questions of democratic anchorage and legitimacy and focus more on the management of the interaction process itself in which outcomes are achieved.

The normative view is that governance networks contribute democratic anchorage and legitimacy in several ways (Fung and Wright 2001; Papadopoulos 2000). First, the creation of new institutions offers greater opportunities for participation in the policy process. This reengages citizens with democratic practice, and also increases the quality of information available to government on citizens' needs and preferences. Second, governance networks when predicated on the basis of deliberative and other democratic practices deriving from the communicative theory of rationality - engender both a democratic ethos and consensual decision-outcomes that transcend and accommodate partial preferences. Third, the structured nature of governance network institutions enables participation across the various phases of the policy process, from agenda setting through evaluation and into implementation. This builds coalitions committed to realising policy intent, thus enhancing the probability of successful delivery. Finally, the process of interaction and debate in arenas that are semiformal (i.e. they have few constitutional rules) and semi-public (i.e. they typically meet beyond the view of the ordinary citizen) builds a measure of social capital, integrating citizens into a trust relationship with government (McLaverty 2002). The complementary view thus 
sees governance networks as additions to more traditional forms of decision-making and accountability.

The view that governance networks are complementary to representative democratic institutions is attractive at an intuitive level. It appears to maintain the core institutions that, although under pressure, still provide the most effective means of resolving values in a way that has both input and outcome legitimacy. But at the same time it creates arenas around the periphery of the representative system that can accommodate the changed nature of society and the complex policy problems it faces. Governance networks are a helpful adjunct to representative democracy, the more so because their constitutional status and external regulation are loosely defined. Such flexibility - or, perhaps, ambiguity - enables this quasigovernmental form to more easily bridge the boundary between the formality of the state and the informality of civil society. It is to be expected that there will be constraints on the jurisdiction of governance network institutions set by the elected legislature or political executive, and that they will reserve authority over decisions regarding fundamental value choices. In this sense, governance networks can be understood as being concerned with the questions of low politics rather than high politics. Being some way down the policy hierarchy - and perhaps even in the area of management rather than politics - means that the problem of democratic deficit, posed by the 'incompatible' perspective discussed in the previous section, is seen to be irrelevant. Governance network institutions are essentially dealing with managerial issues, and indeed overcome some of the problems of managerialism by opening public servants to greater interaction with affected citizens and other actors. Elected politicians, then, exercise a supervisory oversight on governance networks, but frequently are absent because of the low level nature of the decisions being made. 


\section{Conjecture 3: the Transitional Conjecture}

A third perspective on the relationship between representative democracy and governance networks is that it is part of a transitional process from state-centric government to a network form consisting of decentred, distributed nodes of authority. Due to globalisation, information technology (Castells 1997) and diminishing social ties (Putnam 1995), the traditional political system is losing its importance as a governing system. This is also reflected in the drastic decline of party membership in all Western Countries (Sociaal Cultureel Planbureau 2002). Consequently the transitional conjecture sheds a completely different light on the relation between representation democracy and governance networks. This perspective interprets the tensions between the two forms as a sign of large and lasting changes to come in society in which representational democracy will no longer be the preeminent mode of governance.

Research shows that there has been a significant expansion in and experimentation with new forms of citizen participation (Klijn and Koppenjan 2000; Lowndes, Pratchett and Stoker 2001), which some authors understand as marking a major shift in the dominant mode of governance (e.g. Fung and Wright 2001). Empirical studies show that deliberative stakeholder participation is difficult to combine with the actors and mechanism of representational democracy (Klijn and Koppenjan 2000; Edelenbos 2000, 2005; Edelenbos and Monninkhof 2001; McLaverty 2002). Engaging citizens in the development of policy often brings them into conflict at the end of the process with elected bodies like parliament or municipal councils. The studies cited above find that politicians initiated interactive decisionmaking, but were reluctant to support the process or utilise the outputs in their decisionmaking. Klijn and Koppenjan (2000) explain this with reference to politicians’ fear that interactive decision-making threatens their primacy as decision-makers (the incompatibility 
thesis), but equally it could be understood as the inevitable friction involved in the transition from one governance system (representational democracy with vertical lines of accountability and power) to another (governance networks with more horizontal forms of accountability and power). Thus, the forms of citizen and stakeholder engagement could be an indication of a new mode of interactive governance, as well as a symbol of the need for politicians and administrators to acquire support, to generate new solutions and to strengthen the legitimacy of their decisions (Fisher and Forrester 1993; McLaverty 2002; Klijn and Koppenjan 2000; Papadopoulos 2003; Schon and Rein 1994). So the paradox that politicians are initiating new forms of participation on the one hand, and are reluctant to accept the consequences of a limitation of their own power on the other, may be very well explained by the transition conjecture: that politicians and the institutions within which they are located are struggling to resolve the contradictions between the duality of representative democracy and governance network in the process of transition from one to the other.

In the transitional perspective the problems of governance networks and representational democracy are closely related to changes in society and the nature of decision-making. A central feature of the transition process is the form of decision-making. This arises because the network society is characterised by individualisation and plurality of values (Sociaal Cultureel Planbureau 2000), by division of resources and knowledge, and horizontalisation of power and authority. Decision-making has become more complex by the involvement of many actors, by the fact that problems often transcend traditional borders of actors and networks and by the fact that often complicated value conflicts are involved. As a result, the transition conjecture sees decision-making as a complicated negotiation processes about values, often in the form of deliberative democracy (see Forrester 1989; Fisher and Forrester 1993; Hajer and Wagenaar 2003), in which the process cannot be 
separated from the outcome, as it is in more classical perspectives on democratic decision making. It is precisely because we do not know the solutions for problems in advance, because so many values are at stake and have to be reconciled, and that resources and knowledge are dispersed that judgements and the general interest have to be constructed during the decision-making process (Forrester 1989; Kickert, Klijn and Koppenjan 1997; Hajer and Wagenaar 2003; Koppenjan and Klijn 2004).

If the process itself is the vehicle in which values are formed and judgements are constructed, than the conditions of this process become crucial. This points to a different role of elected politicians as mediators and facilitators of this process. The elected politician can hardly be the central administrator, undertaking value weighting at the end and standing for the general interest. The general interest is a concept, which is alien to the transitional perspective because it stresses that various actors have different interests and that these have to be reconciled in interactions. Instead, politicians should guarantee open access to the process, set initial conditions for the solutions, and check the outcomes on their values. But they could also facilitate the process more actively by using their legitimacy to enhance the importance of the process or by guiding the solution seeking process (Koppenjan and Klijn 2000; Sørensen 2002). This last role however requires a very active process management role, which is completely different than the more passive role and judgement afterwards that is common in most tradition decision-making processes

From the transition perspective democracy becomes more a societal model than a representational model. Democracy becomes a process of deliberation that has to be organised and guided carefully to enhance the open character of it. It also becomes a model that has to be supported by multiple forms of accountability and not only by political 
accountability by means of the primacy of politics. In the transitional conjecture, democracy is a design task to be implemented in real life practice of governance networks. It is both a high ideal but also a very pragmatic managerial task.

\section{Conjecture 4: the Instrumental Conjecture}

The instrumental conjecture rests on the view that powerful governmental actors increase their capacity to shape and deliver public policy in a complex world through the instrumental use of networks. Networks provide an instrument to structure the inputs to and outcomes from the policy process so that their alignment with dominant agendas is increased. This perspective applies a more critical reading to the relationship between governance networks and representative democracy than is found in the approaches previously discussed. Theoretically, the instrumental approach can be located either in a notion of local elite strategies or the wider debate about changing forms of social regulation in a neo-liberal context. In either case, the instrumental perspective starts from the premise that the interests of governmental actors are relatively immutable and exist prior to any wider engagement with stakeholders. Governance networks provide a means of reinforcing these dominant interests (through the input structure) and realising them (through the output structure). In contrast, both the complementary and transitional approaches assume that interests are transitive, being refined and redefined through dialogue and deliberation between elected politicians and their officials on the one hand, and the various publics on the other.

Empirical studies in France and England provide a way into this perspective. In the French case, Le Galès (2001) analyses the development of a governance network in Rennes as a product of elite strategies. He shows that the power of the City Council enables it to shape local policy networks in order to realise collective political objectives. In the case of culture, 
the City Council deliberately set out to create a policy network in order to raise the city's profile in this field and also to control spending and the associated risks. This involved redefining the relationships between recipients of cultural funding, the city council, and top officials and bureaucrats in the cultural ministry in Paris in ways that emphasised sound management, especially of projects that would promote the city's cultural image. Beyond this core network is a wider periphery of smaller organisations with more limited resource exchanges with the city council. Le Galès observes that the city council occasionally influences and organises this policy community in order to attract support for its own priorities. The political legitimacy accorded to the city council and its key agent (the deputy mayor responsible for this policy arena) together with its exchanges with other significant political actors (national ministries and cultural bodies) enables it to adopt an instrumental strategy towards the governance network. The city council's authority to structure networks provides it with a powerful means of extending and reproducing its policy agenda into a new arena, and enhancing the possibilities of realising its broader collective project for the locality. Coincidentally, Wälti and Kübler (2003) point to the danger of pluralistic networks being subject to 'colonisation' by powerful state actors as participants comply with the 'official' view of problems and solutions, or run the risk of being excluded from the network and the resources to which it provides access.

The English studies arise from empirically based critiques of 'governing without government' (Bache 2000; Davies 2002; Skelcher, Mathur and Smith 2005). These studies challenge two of the neo-pluralist pillars of the 'governing without government' thesis - (a) that networks are self-organising and (b) that government is one amongst many players in a game of resource exchange. They also question the assumption of horizontality that is conventional in much of the north European literature in this field of study. The English literature draws on case analysis of governance networks at regional and local levels to argue that the role of 
national government is somewhat different to that presented in Rhodes’ approach. They conclude that national government is a powerful actor that introduces measures to create and manipulate networks in order to realise its projects. For example, Skelcher, Mathur and Smith (2005) shows that governance networks at the sub-national level can be categorised into three types - club, polity and agency. Clubs are closest to the notions of mutuality and selforganisation reflected in the 'governing without governance' framework, bringing together a set of actors with a broad interest in coordinating approaches to a policy sector or locality. Polity networks involve the creation of a new political community, for example through the election of residents onto the board of a regeneration company. In both cases, however, there is evidence of such forms arising directly as a result of national government policy, largely in compliance with the network creation measures necessary to obtain additional funding. The third type of network form is the agency. This is a network, and associated organisation, created specifically in response to a national government mandate. Its role is to be the delivery arm for a national policy initiative that requires inter-organisational cooperation at the local level. This research team's analysis of 26 'partnership’ bodies that formalised local club, polity and agency networks identified that 15 were integrated into vertical performance management systems that connected them to regulation by national government. This evidence of vertical integration adds further weight to the instrumental perspective on governance networks / representative democratic relationships.

In both cases, therefore, governance networks come after rather than before the definition of political projects, and are associated with a powerful and legitimate political actor proactively creating or reshaping networks. It is these characteristic that gives it its instrumental function. In this conjecture accountability is secured by the strong involvement of political office holders who remain responsible. Other accountability measures (such as performance 
indicators or organisational arrangements) are designed to support the accountability of the 'central political stakeholder'. In that sense this conjecture comes closest to the first conjecture. The general applicability of this perspective, however, is limited by the national contexts within which the empirical work was undertaken. Both France and England have strong national political and governmental institutions that reach deep into the locality. In this respect, one might expect these actors to employ the opportunity offered by governance networks in order to realise their projects. Authors who have drawn on neo-Foucauldian and neo-Gramscian analyses (e.g. Rose and Miller 1992) have developed this explanation further ${ }^{3}$.

The notion that the governance network is an instrument available to representative democratic institutions has been a sub-text within the field. The predominant perspectives reflect assumptions of resource exchange within a network of mutual relationships. The instrumental perspective places questions of purpose and power firmly on the agenda, and sees governance networks as a tool in a larger political contest, where organs of representative government have both the legitimacy and authority to shape networks to advance their ends.

\section{APPLYING THE CONJECTURES: THREE CLASSICAL THEMES}

The four conjectures provide different explanations of the relationship between representational democracy and governance networks. They can be used in two ways. The first use of the conjectures is as a framework for mapping the existing literature in the field, in order to clarify the pattern of research activity, theoretical interest, and empirical evidence.

\footnotetext{
${ }^{3}$ Although not concerned with the relation between representational democracy and governance networks one can also find this strong instrumental view in many of the US literature on service delivery. Networks in this literature are instrumental in getting good service trough contracting by public principles. One could even say that the relation between governance networks and representational democracy is not problematised at all.
} 
This provides a basis for establishing the existing level of knowledge and identifying those questions that have been neglected. Some initial indication of the literature is provided in our discussion of each conjecture, although we have not sought to undertake a full review and also recognise that individual authors' work may not locate neatly within one conjecture. The second use of the conjectures is to provide a reference point for the identification of more detailed research questions and design of focused investigation, in order to provide greater rigour for research in this field. We think that this is a key task, given the normative flavour of the debate thus far and the paucity of well-designed, sceptical investigations, and we consider the implications in the remainder of this paper.

A helpful staring point for this discussion is to revisit the recent debate about Marsh and Rhodes’ policy networks approach. Dowding’s analysis of this body of research injects a critical edge. One of his central contentions is that 'the network' provides a metaphor for understanding the policy process, but that the development of explanatory models is likely to require attention to theories of bargaining and power (Dowding 1995; Dowding 2001; Marsh 1998). In a similar vein, the work of governance networks researchers should not be constrained by a self-referential literature in this developing field, but also should be connected to the traditional concerns of public administration. Public administration has a number of enduring, fundamental problems it seeks to investigate and resolve (Frederickson 1997). These problems are inherent to governance networks, but are seldom expressed or explicitly considered. These longstanding concerns include, amongst other themes, questions about the distribution and form of power in society, the nature and formulation of the public interest, and the role and relationship of public servants and politicians. We illustrate this point by outlining how our conjectures cast light on these three classic problems in public administration, and outlining the research questions that arise. 


\section{Where does power lie?}

Questions about the form and location or power in a system of representative democracy have preoccupied researchers in public administration and political science back into history. However, the analysis of power is seldom at the forefront of the analysis of governance networks because of the powerful underlying assumptions of cooperation, mutuality and consensus between actors in the network. We can illustrate this by considering how the four conjectures treat this question.

The answer is clear for the incompatibility and instrumental conjectures: power is associated with the authority of elected politicians to make strategic decisions, that is, acts that create a stream of consequential lower-order decisions for other actors in the network. Where they differ is in the ideological import of politicians' power. The incompatibility conjecture rests on the classic view of representative democracy in liberal societies, with political decisionmakers articulating and mediating between different values. This is informed by theories of electoral competition, pressure group politics and the median voter hypothesis, and predicts that the ideological component of the governing party's agenda is moderated in the interests of some generalised pubic good. From the instrumental perspective, however, the power of politicians is seen from the perspective of the theory of credible commitment - specifically, believability of intent and sustainability of action over time. A number of researchers have recently used the theory of credible commitment to explore the ideological imperatives informing the design of quasi-autonomous agencies (Bertelli forthcoming; Elgie and McMenamin 2004; Huber and Shipan 2002). Governance networks share some of the arm's length characteristics of quasi-governmental agencies, and also subject to a level of conscious design, for example through the use of special funding regimes, the creation of nodal 
organisations ('partnerships'), or emergence of club or polity-like groupings (Skelcher 2005). The power of politicians, from this instrumental conjecture, thus lies in their capacity to act as authoritative principles able to create and change the incentive structure of governance networks in order to meet the requirements of credible commitment. As political ideology changes, so we would expect the pattern of incentives and hence structure and content of the governance network to change.

The complimentary and transitional conjectures have different views on the power of elected officials. The complementary perspective builds on a pluralist theory of political power. While elected officials have the ultimate decision authority, governance networks facilitate its sharing with various societal groups, who in their turn provide elected politicians with support, knowledge and implementation capacity. This process, theoretically, enhances civic engagement in public policy and strengthens the plurality of the system. It is the transitional conjecture that has the most deviant view on the notion of power. From this conjecture the notion of power dissolves in the network and mainly returns as veto power of many different groups to oppose decisions. The transitional conjecture stresses the lack of power to achieve positive goals because every actor is dependent on the cooperation of various actors and their resources. So the transitional perspective sees the elected official as one of the actors but not necessarily the most powerful and certainly not the only powerful actor. That does not mean that there are no power differences, but they are explained by actors' resources and the institutional rules of the network. Most of the time these power differences are not decisive for achieving policy outcomes. Power is relocated from the political institutions of representative democracy to the governance networks itself, which of course fits the notion of transition (Castells 1997; Hajer and Wagenaar 2003). 


\section{How is the general interest understood?}

The definition of the general or public interest has been a matter for debate in relation to democratic theory, and now emerges in new ways as researchers, policy makers and managers engage with governance networks. Although the notion of the 'public interest' has been subject to critical analysis from theoretical and empirical points of view (Downs 1957; MacPherson 1977; Schumpeter 1943), the concept still retains a significant role in public administration theory and practice, even if only in symbolic terms.

The incompatibility conjectures reflects this view that the general interest is still an important concept. This is because it holds the old view that elected office politicians should be the prime actors to weight the values at stake and thus should have the decisive say about which values should prevail. So the incompatibility perspective sees the general interest as something that is constructed by the programmes that prevail in elections, and is guarded by those politicians who form the government or majority in the legislature.

The other three conjectures problematise the notion of a general interest. All three recognize that the general interest as such is a problematic concept in a fragmented world in which even public actors themselves sometimes fundamentally disagree on the right policy measures, political parties do seem to have only a few members and decision-making processes are very complex. But each of the conjectures has a different answer to the idea of the general interest. The complementary perspective sees it emerging from a process of deliberation between elected politicians, civil society actors and other stakeholders in the network. Deliberation suggests a form of communicative rationality in which a common understanding of values and actions emerges from diverse starting positions. In this sense, the general interest is not an input to the policy process in governance networks, but an outcome. It is developed during 
the process and means that actors are engaged in complex interaction processes to develop solutions that satisfy a wide range of values, which are at stake. From the perspective of the instrumental conjecture, the general interest is translated into (and effectively substituted by) concrete signals like output performance criteria, accountability measures or consumerist devices. The idea behind this is that networks are used to deliver improved policy outcomes in line with ideological predispositions of politicians (following from the theory of credible commitment discussed above). Finally, the issue from the perspective of the transitional conjecture is not so much whether the general interest can be defined, as the changing locus of the definitional process and the struggles that this involves. The emergence of particularistic political groupings based on neighbourhood, ethnicity, environment, and so on challenges the idea of a single general interest defined through the representative democratic process, and opens the door to more complex interaction processes that are identified in the complementary conjecture.

\section{What is the role of public managers?}

The final question we consider concerns the role of public managers in the context of the four conjectures. In the classical Weberian view of bureaucracy, civil servants are the humble servants of the elected politicians making their political programmes into reality. This is of course strongly implied by the notion of the primacy of politics, which assumes that elected politicians are responsible for the deeds of their subordinate civil servants. Despite the challenges to this view, the basic ethos remains and forms an important part of the theoretical infrastructure of public administration and ethics (Cooper 1998; Peters 2000). This position is reflected in the incompatibility conjecture. Elected office holders are the prime source of authority, and hence the creation of governance networks that draw administrators into the 'grey zone' of policy-making with citizens and interest groups is undesirable. It challenges 
the theoretical - and to some extent empirical - boundary between policy decision and policy execution.

The three other perspectives have a slightly different view on this topic. All perspectives recognise that the significance of governance networks is in opening a new space for questions that were seen as being in the realm of elected politicians to be relocated into arenas where politicians (if they are there at all) are likely to be in the minority, and where managers play a greater role as policy entrepreneurs (Kingdon 1984; Kickert, Klijn and Koppenjan 1997; Skelcher, Mathur and Smith 2005). This introduces problems of legitimacy that, to date, have not seriously been considered. However the way these three perspectives view the relocation of the 'political' into the 'managerial' is rather different. It is not understood as a problem when viewed from the complementary conjecture, because it holds that the larger influence of managerial activities in realizing and weighting (political) values can co-exist with the ultimate authority of elected politicians because of the contribution they make to securing agreements across diverse publics and adding information to enhance policy design and implementation. However this condition requires good connections between managerial activities in the governance network and elected politicians in representative democratic institutions. The transitional conjecture presents a different view. It seems to start from the assumption of institutional change. Within this, managerialism is the dominant technology through which this change is effected (Clarke and Newman 1997), augmented by the arm’s length location of governance networks from elected political authority. From this perspective, the role of politicians is to be the meta-governors steering the overall direction of system change, while managers undertake the detailed design and implementation processes. Finally, the instrumental perspective views public managers as the agents of politicians in delivering ideologically driven programmes. Because of the complexity of the system they 
are accorded a high degree of discretion, which is underpinned by a strong public service ethos. It accepts that managers are important actors with high discretion (and far more important than the classical view permits), but seeks procedural conditions to hold them accountable. Specific technologies are employed to monitor and guide their actions, including performance management systems and indicators.

\section{CONCLUSION}

The study of governance networks has only recently begun to engage in systematic research concerning its relationship with different forms of democracy. To date, the field has been preoccupied by with the meta-level debate about changes in modes of governance, based on the market-hierarchy-network triptych. Only now are other questions being surfaced, and more rigorous analyses being undertaken. The critical edge to debates in the field have also been contaminated by the normative flavour of some governance network literature, especially that which starts from the theoretical premise that networks are predominantly characterised by horizontal relationships, self-steering and pluralism, and that too easily draws an association with deliberative forms of democracy.

The value of the conjectures as heuristic devices is that they enable greater sensitivity to the nuances and complexities of the relationships between governance networks and democracy. We see this approach making a particular contribution by enabling analysis and theorising of the field to encompass a higher degree of contextual specificity. At present, research draws conclusions from empirical studies in particular temporal, spatial and political contexts, but the significance of these contexts is often lost on those who draw on such studies. Thus, for 
example, conclusions from research in societies whose governmental norms are consensual is utilised in work on countries with more antagonistic cultures. The same process takes place between countries with highly centralised governments and those where there is greater local autonomy. The conjectures can assist us in this research to specify specific themes and clarify their internal logic. We can then identify the nature and the importance of various themes and tensions and see how they are connected to specific contexts (both country contexts or specific decision contexts such as service delivery or infrastructural decision making). We might find different tensions but also differences in the importance of tensions in various contexts.

Taking research forward in this way offers the prospect of rediscovering the critical edge in the field and developing theory that is more attuned to contextual conditions. The challenge for researchers in the field is to develop a more rigorous and systematic assessment of the governance network literature in order to build theoretical propositions that can form the basis of research programmes. The four conjectures offer a starting point, but further careful work is needed to establish the detailed theoretical relationships within each. Such clarity will offer the basis for fresh thinking on the relationship between governance networks and the democratic infrastructure and practices of societies. 


\section{REFERENCES}

Bache, I. 2000. 'Government within governance: network steering in Yorkshire and the Humber, Public Administration, 78, 3, 575-92.

Bardach, E. 1977. The Implementation Game: What Happens after a Bill Becomes Law? Cambridge, Mass: M.I.T. Press.

Bertelli, A. (forthcoming) 'The role of political ideology in the structural design of new governance agencies’ Public Administration Review.

Castells, M. 1997. The Power and Identity. Cambridge: Blackwell Publishers.

Clarke, J. and J. Newman. 1997. The Managerial State: Power, Politics and Ideology in the Remaking of Social Welfare. London: Sage.

Cooper, T. L. 1998. The Responsible Administrator: An Approach to Ethics for the Administrative Role. $4^{\text {th }}$ ed. San Francisco, CA.: Jossey-Bass.

Davies, J. 2002. 'The governance of urban regeneration: a critique of the 'governing without government' thesis', Public Administration 80, 301-22.

Dogan, M. (ed.) 1975. The Mandarins of Western Europe; The Political Role of Top Civil Servants, London: Sage.

Dowding, K. 1995. 'Model or metaphor? A critical review of the policy network approach' Political Studies, 43, 136-158.

Dowding, K. 2001. 'There must be an end to confusion: policy networks, intellectual fatigue, and the need for political science methods courses in British universities.’ Political Studies 49, 1, 89-105.

Downs, A. 1957. An Economic Theory of Democracy. Harper: New York. 
Edelenbos, J. 2000. Proces in vorm; procesbegeleiding van interactieve beleidsvorming over locale ruimtelijke projecten, Lemma: Utrecht.

Edelenbos, J. and E.H. Klijn. 2006 forthcoming. 'Managing stakeholder involvement in decision-making: a comparative analysis of six interactive processes in the Netherlands.' Journal of Public Administration Research and Theory

Edelenbos, J. and R.A.H. Monninkhof (eds.) (2001) Lokale interactieve beleidsvorming, Utrecht: Lemma.

Elgie, R. and I. McMenamin. 2005. ‘Credible commitment, political uncertainty or policy complexity? explaining variations in the independence of non-majoritarian institutions in France’. British Journal of Political Science 35, 531-48.

Fischer F. and J. Forester. 1993. The Argumentative Turn in Policy Analysis and Planning. London: Duke University Press.

Forester, J. 1989. Planning in the Face of Power, California Press, Berkeley.

Frederickson, H. G. 1997. The Sprit of Public Administration. San Francisco, CA.: JosseyBass.

Freeman, J.L. and J.P. Parrish Stevens. 1987. ‘A Theoretical and Conceptual Re-examination of Subsystem Politics.’ Public Policy and Administration. 2, 1, 9-24.

Fung, A. and E. Olin Wright. 2001. 'Deepenig Democracy: Innovations in Empowered Participatory Governance.’ Politics and Society, 29, 1, 5-41.

Hajer, M. and Wagenaar, H. (eds.) 2003. Deliberative Policy Analysis: Understanding Governance in the Network Society, Cambridge: Cambridge University Press.

Heisler, M.O. 1974. 'Patterns of European politics: The European ‘polity’ model’, in M.O. Heisler (ed.) Politics in Structure: Structures and Processes in Some Post-industrial Democracies. New York: David McKay. 
Hjern, B. and D.O. Porter. 1981. 'Implementation structures: a new unit for administrative analysis’ Organizational Studies, 3, 211-37.

Huber, J. D. and C. R. Shipan. 2002. Deliberate Discretion? The Institutional Foundations of Bureaucratic Autonomy, Cambridge: Cambridge University Press.

Kickert, W.J.M., E.H. Klijn and. J.F.M. Koppenjan (eds.) 1997. Managing Complex Networks: Strategies for the Public Sector. London: Sage

Kingdon, J.W. 1984. Agendas, Alternatives and Public Policies. Boston: Little, Brown \& Company.

Klijn, E.H. and J.F.M. Koppenjan. 2000. ‘Politicians and interactive decision-making: institutional spoilsports or playmakers.' Public Administration , 78, 2, 365-387.

Koppenjan, J.F.M., A.B. Ringeling and R.H.A. te Velde (eds.) 1987. Beleidsvorming in Nederland. 's-Gravenhage: Vuga.

Koppenjan, Joop and Erik-Hans Klijn. 2004. Managing Uncertainties in Networks; a network approach to problem solving and decision-making. London: Routledge.

Laumann, E.O. and D. Knoke. 1987. The Organizational State: Social Choice in National Policy Domains. Wisconsin: University of Wisconsin Press.

Le Galès, P. 2001. 'Urban governance and policy networks: on the boundedness of policy networks. A French case.’ Public Administration 79, 1, 167-84.

Lijphart, A. 1984. Democracies: Patterns of Majoritarian and Consensus Government in Twenty-one Countries. New Haven: Yale University Press.

Lowndes, V. 2001. 'Rescuing Aunt Sally: Taking institutional theory seriously in urban politics.' Urban Studies 38, 11, 1953-71.

Lowndes, V., L. Pratchett and G. Stoker. 2001. 'Trends in public participation: part1 - Local government perspectieves.' Public Administration 79, 1, 205-22. 
MacKinnon, D. 2000. 'Managerialism, governmentality and the state: A neo-Foucauldian approach to local economic governance’. Political Geography 19: 293-314

MacPherson, C.B. 1977. The Life and Times of Liberal Democracy, Oxford: Oxford University Press.

Marsh, D. 1998. 'The development of the policy network approach’ in Marsh, D. (ed) Comparing Policy Networks. Buckingham: Open University Press

Marsh, D. and R.A.W. Rhodes (eds.) 1992. Policy Networks in British Government, Oxford: Clarendon Press

McLaverty, P. (ed.) 2002. Public Participation and Innovations in Community Governance, Aldershot: Ashgate

Milward, H.B. and G.L. Wamsley. 1985. 'Policy subsystems, networks and the tools of public management.' in: K.I. Hanf and Th.A.J. Toonen. Policy Implementation in Federal and Unitary Systems. Dordrecht: Nijhoff.

Papadopoulos, Y. 2000. 'Governance, coordination and legitimacy in public policies.' International Journal of Urban and Regional Research. 24, 1, 210-23.

Papadopoulos, Y. 2003. 'Cooperative forms of governance: Problems in democratic accountability in complex environments.' European Journal of Political Research 42, 473-501.

Peters, B. Guy. 2000. The Politics of Bureaucracy. $5^{\text {th }}$ ed. London: Routledge.

Pierre, J. and B. Guy Peters. 2000. Governance, Politics and the State. Basingstoke: Macmillan. Putnam, R.D. 1995. 'Tuning in, tuning out: the strange disappearance of social capital in America.’ Political Science and Politics. 12, 664-83.

Rhodes, R.A.W. 1988, Beyond Westminster and Whitehall: The Sub-central Governments of Britain, London: Unwin Hyman. 
Ripley, R.B. and G. Franklin. 1987. Congress, the Bureaucracy and Public Policy. Homewood Ill.: Dorsey.

Rose, N. and P. Miller. 1992. 'Political power beyond the State: problematics of government.' British Journal of Sociology 43, 2, 174-205.

Schon, D. A. and M. Rein. 1994. Frame Reflection: Toward the Resolution of Intractable Policy Controversies. New York: Basic Books.

Schumpeter, G.A. 1943. Capitalism, Socialism and Democracy. London: George Allen \& Unwin.

Skelcher, C. 2005. 'Jurisdictional integrity, polycentrism and the design of democratic governance.' Governance 18, 1, 89-110.

Skelcher, C., N. Mathur and M. Smith. 2005. 'The public governance of collaborative spaces: Discourse, design and democracy.’ Public Administration 83, 3, 573-96.

Sociaal Cultureel Planbureau. 2000), Sociaal Cultureel Rapport; Nederland in Europa [Social and Cultural Report: The Netherlands in Europe]. 's-Gravenhage.

Sørensen, E. 2002. 'Democratic theory and network governance.' Administrative Theory and Praxis 24, 4, 693-720.

Sørensen, E. and J. Torfing. 2003. 'Network politics, political capital and democracy’, International Journal of Public Administration 26, 6, 609-34.

Sullivan, H. and C. Skelcher. 2002. Working Across Boundaries: Collaboration in Public Services. Basingstoke: Palgrave Macmillan.

Wälti, S. and D. Kübler. 2003. “”New governance” and associative pluralism: the case of drug policy in Swiss cities.' The Policy Studies Journal 31, 4, 499-525.

Wälti, S., D. Kübler and Y. Papadopoulos. 2004. 'How democratic is “governance”? Lessons from Swiss drug policy’ Governance 17, 1, 83-113. 
Wamsley, G.L. 1985. 'Policy subsystems as a unit of analysis in implementation studies: A struggle for theoretical synthesis.’ in: K.I. Hanf and Th.A.J. Toonen. Policy Implementation in Federal and Unitary Systems. Dordrecht: Nijhoff.

\footnotetext{
${ }^{\mathrm{i}}$ And the literature on this topic keeps increasing, as recent special issues of the Scandinavian Political studies (vol 28, no3 2005) and European Political Studies (2005, vol. 4 no.3) illustrate.
} 